\title{
The Impact of the UK Corporate Governance Code 2010 on Earnings Management around Mergers and Acquisitions
}

\author{
Michael Yipake Banseh ${ }^{1} \&$ Ehsan Khansalar ${ }^{1}$ \\ ${ }^{1}$ Kingston University London, Kingston Upon Thames, UK \\ Correspondence: Ehsan Khansalar, Kingston University London, Kingston Upon Thames, UK. E-mail: \\ e.khansalar@kingston.ac.uk
}

Received: July 9, 2015

Accepted: July 29, 2015

Online Published: January 25, 2016

doi:10.5539/ijef.v8n2p1

URL: http://dx.doi.org/10.5539/ijef.v8n2p1

\begin{abstract}
Several studies revealed earnings management (EM) around mergers and acquisitions (M\&As) by both acquirers and target firms. Rosa et al. (2003) suggest that a systematic EM is associated with the use of stock as payment in takeovers. This and other corporate malpractices have prompted authorities to tighten regulations by passing the United Kingdom (UK) Corporate Governance (CG) Code to guide companies in the UK in their corporate management and financial reporting.

This study is to investigate the impact of the UK CG Code on accruals EM around M\&As in the UK. The study applied the Modified Jones (1991) model as modified by Dechow et al. (1995) and the Pearson Product Moment Correlation in analysing a sample data from 66 companies listed on the LSE that have undertaken M\&As within the period of January 2007 to December 2014. The results produced by the modified Jones model indicate some level of income increasing discretionary accruals in the pre-CG period but showed an opposite situation in the post-CG period. A test for significance indicates the means of pre-CG discretionary accruals and post-CG discretionary accruals were different and significant. The hypothesis that "the level of earnings management around mergers and acquisitions in the UK has significantly reduced after the enactment of the UK Corporate Governance code 2010" was therefore accepted.

Results from the Pearson Correlation Coefficient were inconclusive on EM but indicate some changes in the level of activities in the earnings between the two periods. This may also points to some effect of CG Code on the reported earnings of these companies. The results from this study is consistent with existing studies that evince the effectiveness of CG in controlling EM as Hsu and Koh (2005); Osma (2008) suggest that best corporate governance practices minimise EM and reduce fraud drastically.
\end{abstract}

Keywords: corporate governance, earnings management, mergers and acquisitions

\section{Introduction}

\subsection{Background}

Earnings management (EM) has prompted attention to regulators and other statutory bodies regarding some happenings in the corporate world in the pass and in recent times. Issues relating to EM and Corporate Governance (CG) failure have prompted nations to legislate in order to curb this act. For example, Sarbanes Oxley Act of 2002 in the US and the UK revised combined code, 2008 and most recently, the UK CG Code of 2010. EM practices are considered to be in the increase and have led to the collapse of Enron and World.com in the US and also believed to have significantly contributed to several corporate failures that triggered the 2007/2008 financial crisis with its debilitating effect throughout the world. All of these inappropriate acts involved the deliberate manipulation of financial records to present a false picture of performance to influence investors amongst others.

\subsection{Motivation}

Available literature provides enormous evidence about EM around mergers and acquisitions elsewhere including the UK (Botsari \& Meeks, 2008). In emphasizing on the role of CG in containing earnings management, Keasey et al. (2005) suggest that reforms of corporate governance in the UK was in response to some major happenings in the corporate world including EM and corporate failures. To be able to improve on the current CG Code, it is important to be able to demonstrate how effective the existing Code has performed in achieving its intended 
purpose. The motivation for this study is to document and provide evidence on the effectiveness of the UK CG Code 2010 in curbing or reducing EM around M\&As. This will help regulators to understand the area of the code that needs fine tuning. This study will therefore provide valuable information in that direction.

\subsection{Aims and Objectives}

The aim and objective of this study is to test the effectiveness of the UK CG Code 2010 in minimising accruals based earnings manipulation around M\&As and to understand EM practices around M\&As. The study will employ DA detecting models in establishing the existence of income enhancing or decreasing activities around M\&As in the UK in so doing assessing the impact of the UK CG Code 2010 on accruals EM. The study investigates the reasons for such practices and the tools employed in the practice. It also seeks to understand the evolution of corporate governance practices in the UK and how it contributes in curbing the EM menace, particularly around M\&As. Regarding some other regulations elsewhere in dealing with such practices like the Sarbox case, Cohen et al. (2008) found that it reduce accruals EM significantly but it rather led to a situation where managers shifted to the use of real accounting earnings manipulation.

\subsection{Contribution}

This study contributes uniquely to knowledge in the area of CG and EM around M\&As in the UK. It looks at the effectiveness of CG in controlling EM around M\&As in the UK. This is the first of its kind so far as CG, M\&As and EM in the UK are concerned. Additionally the study provides feedback to regulators as to the effectiveness of the regulations and the subsequent course of action required to ensure good CG, strong financial reporting that will boost investor confidence and increase investments and economic activities in the UK.

\subsection{Structure of Study}

This study is divided into five sections. Section one introduces the study and section two sheds light on previous literature relating to the study and the research question. Section three provides the data sampling techniques and the methodology used in analysing the data. Section four presents the analyses and findings of the study and section five concludes based on the findings and makes recommendations.

\section{Theoritical Background}

\subsection{Introduction}

This section reviews the available literature in relation to EM and M\&As and the motivations for such activity. It also looks at the literature on CG practices and its impact on EM.

\subsection{Mergers and Acquisitions}

Mergers and Acquisitions (M\&As) involve the combination of two or more entities into one, through a purchase acquisition or pooling of interests. In another vein, the Financial Reporting Standard (FRS) 6 defined business combination as "the bringing together of separate entities into one economic entity as a result of one entity uniting with or obtaining control over the net assets and operations of another". In a merger, the two entities are seen as equals who have pooled their resources for a particular purpose, whereas an acquisition is considered as one entity taking over the net assets and operations of another entity as part of its own. Even though a merger in it strict term differs from acquisitions, the two terms are used together in this study to mean a business combination or an acquisition.

\subsubsection{Motivations for Mergers and Acquisitions}

There are several reasons why managers engage in $M \& A s$ even though they pay huge premium to acquire the target. According to Berk and DeMarzo (2014), M\&A results in economies of scale and scope which reduces cost significantly and creates efficiency. Vertical integration leading to better coordination, transfer of expertise from and to acquirers and targets also enable the acquirer to create value to its shareholders. Other benefits they indicate include monopoly and efficiency gains and tax saving from operational losses of targets.

A study by Roll (1986) put forward that acquisitions are motivated by managerial "hubris". Roll (1986) suggests that the underlying motive of bidders is to derive efficiency gains, but hubris leads to overbidding. As a result, the price paid transfers all, or a bigger share of efficiency gains from an acquirer to target shareholders. The resultant effect is that, on average, target shareholders get positive gain, whilst the bidders get negative. This could lead to EM practices in M\&As by acquirer firm aiming to attain a favourable exchange ratio.

M\&As are seen as the quickest and easiest way for firms to expand their operations into new, particularly foreign markets. The motivation for firms to engage in acquisition is the prospects of faster growth. Koumanakos, Siriopoulos and Georgopoulos (2005), argued that merged companies are in a position to provide more benefits 
for shareholders than the individual companies could offer on their own. Mergers could also be desirable to confront foreign competition and create powerful enterprises.

A considerable part of M\&As activities take place in countries with improved accounting standards, stronger shareholder protection and under good economic environment. Quality accounting disclosure affects M\&A positively because good disclosure is an essential factor in identifying viable potential targets. Accounting standards also reflect some level of CG, for the reason that they reduce the scope for expropriation by making corporate accounts more transparent. Rossi and Volpin (2004) reveal that a more active market for M\&As is the effect of a corporate governance regime with stronger investor protection. Countries with better shareholder protection are likely to have relatively more hostile takeover deals, the explanation being that good protection for minority shareholders makes control more contestable by reducing the private benefits of control.

When an acquisition agreement is to purchase the target firm's shares by issuing stock of the acquirer as consideration, the shareholders of the target are given shares of the acquirer as payment for their shares. When stock is issued as the payment method, an exchange ratio is established and agreed by the two firms. The exchange ratio is usually based on the value of the acquiring firm's stock compared to the value of the target firm's stock. This is usually referred to as a stock-for-stock transaction or a stock swap (Goodwin, 2009).

Acquisition can be done through cash purchase, exchange of shares or the combination of both cash and share exchange. In a cash purchase, the acquirer pays for the agreed value of the outstanding shares of the target by cash to the target shareholders. On the other hand, a share exchange is used when the acquirer issues it own shares in exchange for the shares of the target based on the agreed values for the shares of the target. This share exchange is often used when the acquirer believes its shares are overvalued so that the share exchange will give the acquirer an advantage as to the number of shares to be exchanged for the target shares.

However, some studies on M\&As have revealed that the target shareholders benefit the most while the acquirer shareholders are usually losers following an acquisition. A study by Moeller, Schlingemann, and Stulz (2005) showed value destruction for acquiring firm shareholders at the time of announcement and wealth gains for target shareholders. Some other studies found abnormal returns to be positive, suggesting mergers do create value for the acquirer shareholders but they also reveal that target shareholders are winners in mergers with an average three-day return of $16 \%$ (Andrade, Mitchell, \& Afford, 2001). Similarly, Ben-David and Roulstone (2008) reveal underperformance of acquiring firms' stock after acquisition, however, they argue that the underperformance is limited to small stock acquirer. It was further argued by the authors that "limits to arbitrage" for these small firms' stock could be the reason for the stock underperformance.

A possible explanation for the acquirers' post-acquisition poor performance could also be attributed to the used of accounting discretion by acquirer's management to inflate the value of the firm preceding the acquisition announcement .In this case, the acquirer could be creating income enhancing accruals to drive up the value of the firm's stock and end up acquiring the target at a favourable rate of exchange. Upon the completion of the acquisition process, the earnings adjustment will fade away resulting in the stock price underperforming as investors are disappointed by the post-acquisition operating results of the combined firm (Louis 2004). This would often arise when the acquisition transaction consist of some amount of the acquirers stock as consideration. The acquirer may intentionally engage in EM or its management may merely be optimistic about the future of the combined firm and engages in income increasing accruals based on this optimism. The target firm may not be in the position to engage in pre-announcement EM since they would be unaware of the acquisition until the time of announcement. According to Erickson and Wang (1999), the target has virtually no time to manage earnings before the bidder commences the process.

\subsubsection{Mode of Payment in Mergers and Acquisitions}

The incentives for acquisitions to be financed through stock issue or paid for with cash are many and varied. An obvious advantage of using cash for payment is that the same level of control over the company is retained by the acquirer's shareholders. This means new target shareholders do not take possession of a proportion of the acquiring firm's voting rights, as would have happened if the target shareholders were to take shares in the acquisition process. It may be considered important if the acquirer shareholders want to maintain majority control over the firm's shares.

Target shareholders may accept shares as consideration to maintain an interest in the combined entity. In the event M\&As offer genuine benefits, the target shareholders may benefit from it. To the acquirer, the benefit of offering shares is that there is no immediate out-flow of cash. This form of payment takes off pressure on cash flow in the short run. However, the firm may have to consider the effect on the capital structure as this will lead to dilution of existing shareholders' position. According to Myers and Majluf (1984), managers issue stock when 
their stock is overvalued. On the other hand, managers would favour cash acquisitions when the stock is not considered overvalued or possibly, when management have substantial ownership of stock. Also, managers would opt for cash acquisition when the acquiring firm has surplus cash at hand or cheaper debt financing.

\subsection{Earnings Management}

According to Healy and Wahlen (1999), EM involve managers' use of judgment in presenting financial reports and arranging transactions in a manner that alter the financial reports to either mislead stakeholders about the underlying economic performance of the company, or to influence contracts that depend on the reported accounting numbers.

EM takes various forms. These include income smoothing activities in the form of 'cookie jar'. Cookie jar is an accounting reporting scheme in which managers either underreport their company's performance when its finances are doing well, or over report its performance when it is doing poorly. Managers achieve this by generally applying excess revenues from good years to bad years. One-time charges and special items are a couple of areas where a company can manipulate numbers to create cookie jar reserves. While this practice may be common and expected to some extent, it could prove harmful to the company and its investors' interest if overstretched.

Another cunning scheme managers adopt in managing earnings is through big bath charges which follows a different, yet simple line of reasoning in that earnings are made to look worse, at least in the current period. According to Henry and Schmitt (2001), a company will take a large non-recurring loss one year, normally when its earnings are already down, so that future earnings are not burdened. This either results in increased future earnings or reduced the volatility of future earnings. The idea behind this is that, when things are already not looking good, making them worse by clearing out the rubbish does not harm the company's reputation further. Managers are already aware that the market punishes a firm to some extent the same whether it failed to achieve its earnings mark by a little or by a wider margin. Strong and Meyer (1987) suggest such phenomenon occur when there is a change in senior management, especially if the new chief executive comes from outside the company.

Some practices like income smoothing may not necessarily be harmful since it enables managers to present a stable financial performance over a period but does not necessarily change or falsify the underlying economic performance of the entity. Some income smoothing practices allow managers to work strenuously hard to increase their sales and cash-flows in order to meet their targets without necessarily indulging in inappropriate accounting practices. However the concerns arise from the aggressive EM practices that involve the use of unacceptable practice involving manipulating and falsifying records or resorting to sub-optimal accounting policies just to increase short term revenue and earnings which does not necessarily reflect the underlying reality of the firm. A case in point is the United States where there have been several high profile cases in which companies have adapted aggressive accounting practice including the selection of inappropriate accounting policies or unduly stretching judgement beyond what is acceptable when making accounting estimates (Giroux, 2008).

There has been an increased effort to understand and document how firms manage earnings through real activities manipulation as well as accrual-based activities (Zang, 2012; Gunny, 2010). Roychowdhury (2006) explains real activities manipulations of earning as involving managers activities that depart from a firm's normal business practices, undertaken solely with the intention of meeting a certain targeted earnings mark. In his investigation, Roychowdhury (2006) reveals that firms use multiple real earnings management schemes to enable them meet certain reporting benchmarks to avoid annual losses. In particular, his evidence suggests that managers engage in overproduction to lower the cost of goods sold, reduce their discretionary expenditure to soar up reported margins and also provide price discounts to customers to increase short term revenue.

According to Graham et al. (2005), managers favour real EM activities compared to accrual-based EM. The reason for this shift is that real EM activities can be difficult to distinguish from optimal business decisions, and therefore not easily detectable. However, such activities could prove to be significantly costly to the firm in the near future. Consistent with the literature by Graham et al. (2005), Cohen et al. (2008)suggest that mangers have shifted from accrual to real EM in the post Sarbanes-Oxley Act (SOX/Sarbox) period. Their evidence implies that the highly publicized accounting scandals and the regulations that follow the post-SOX period, led managers to shift from accrual-based to real EM activities in order to avoid detection.

\subsubsection{Motivation to Manage Earnings}

Healy and Wahlen (1999) suggest that one of the reasons why managers engage in managing earnings is to 
convey to investors real value of the company, which may sometimes be clouded by compliance with regulation requirements.

The area of concern in EM for regulators is aggressive EM. Among the incentives for managers to manipulate earnings would be their compensation package if tied to performance (Healy, 1985). Kasznik (1999) found that earnings manipulation occurs when managers are under pressure to meet their company's earnings forecast or an analyst forecasts. Also, other studies indicate managers manipulate earnings in their effort to avoid the breach of debt covenants, influence capital market players and to protect the ownership control of firms (Perry \& Williams, 1994).

A study conducted by Rosa et al. (2003) suggests a systematic earnings management is associated with the use of stock as payment in takeovers. They examine EM by bidding firms who offer shares as consideration in their takeover bids and also analyse the bidding firms' share price performance in the period surrounding a takeover to observe whether increased total accruals are associated with excess returns. The conclusion is that stock payment firms have more incentives to engage in EM prior to the takeover announcement than those companies that use cash as a payment model. Goodwin, (2009), suggests an incentive for managers to engage in EM is when firms plan to make an acquisition or merger that involves an exchange of shares for the target. This is done with the objective of increasing the share price of the acquirer in order to reduce the number of shares of the acquirer that will be exchanged for the target.

Consistent with existing literature, Botsari and Meeks (2008) present evidence in the United Kingdom (UK) to affirm the practice of aggressive accrual reporting by UK bidders ahead of share-swap acquisitions undertaken between 1997 and 2001. Analysing Malaysian share acquiring firms from 1991 to 2000, Rahman and Bakar (2002) conclude that acquirers in share for share acquisitions engage in EM in the year prior to acquisition.

The agency theory explains the existence of conflicting interest between managers and shareholders which may encourage managers to engage in certain activities for their private gain. These self interest activities may result in decreasing shareholders' wealth. In order to mitigate the impact of this conflict, the agency theory suggests executive compensation as the appropriate antidote to align the interests of managers and shareholders (Jensen \& Meckling, 1976; Watts \& Zimmerman, 1986). According to Jensen and Meckling (1976), executive compensation may encourage managers to undertake certain transactions that aim to maximise their benefits rather than shareholders'. Consistent with this view, there is evidence that managers manipulate reported earnings upward employing EM activities to meet performance-based compensation targets (Healy, 1985; Dechow \& Sloan, 1991; Cheng \& Warfield, 2005; Bergstresser \& Philippon, 2006; Cazier, 2009).

\subsection{Corporate Governance}

Corporate governance can be described as the system through which business institutions are directed and controlled. It directs and controls management activities towards good governance practices, objectivity and integrity in order to satisfy the objectives of the entity, in so doing serving the needs of shareholders and other stakeholders. In essence, CG specifies the distribution of rights and responsibilities amongst different participants in the corporation such as shareholders, the board, managers and other stakeholders.

Quite extensive research evidence exists on the role of CG in mitigating EM practices. In emphasizing on the role of CG in containing EM, Keasey et al. (2005) suggest that reforms of CG in the UK, which gain much prominence in the early 1990s by the establishment of the Cadbury Committee, was in response to some major scandals in the corporate world including EM practices, excessive executive compensation and corporate failures. It is observed that corporate governance will only be effective in controlling EM if there exist certain factors such as the separation of Chief Executive Officer (CEO) and Chairman, the proportion of outside Directors on the Board, the independent of the audit committee, long-term verses short-term institutional investors (Hsu \& Koh, 2005; Osma, 2008).

\subsubsection{The Role of the Board of Directors and the Audit Committee}

Some previous research attempted examining whether the Board of Directors and its committees can constrain accrual EM (Klein, 2002; Yang \& Krishnan, 2005; Cornett et al., 2008; Laux \& Laux, 2009). Klein (2002) focuses on accrual accounting and investigates the effect of the Board of Directors and audit committee on accrual EM. He finds evidence that outside-Directors presence on the audit committee and board of directors is negatively associated with accruals manipulation. He also points out that when the proportion of outside directors declines, the level of discretionary accruals increase steadily. On the whole, Klein (2002) reveals that higher proportion of outside Directors leads to a lower level of EM and also results in greater scrutiny of the accounting processes in the firms. 
Consistent with existing literature, Osma (2008) provides additional evidence on independent board role in curbing real activities manipulation. Particularly, Osma (2008) investigates the restraining effect of Board independent on the association between $\mathrm{R} \& \mathrm{D}$ manipulation and the pressure of the capital market to meet earnings benchmarks. In her study, a sample of 3,438 UK firms was examined over the period 1989 to 2002 and the evidence suggests that independent Directors reduce R\&D manipulation. Furthermore, the study attributed short-term pressure and/or a previous failure to meet earnings target as the probable motive why firms reduce R\&D expenses. In addition, Osma (2008) finds that a high proportion of inside Directors serving on the Board often lead to short-term sub-optimal managerial decisions such as reduction in advertising and R\&D expenses.

\subsubsection{The Role of Institutional Ownership}

Several developments in the field of CG have rekindled interest in finding out whether the presence of institutional investors lessens the practice of earnings manipulation (Bushee, 1998; Chung et al., 2002). For instance, Bushee (1998) examines the relationship between institutional investors and the sudden reduction of R\&D expenditure in order to meet earnings targets. A sample of US firms covering the period 1983-1994 and focusing on prior year earnings targets provides evidence that the presence of well-informed institutional investors stops managers from reducing $R \& D$ expenses to meet the previous year's earnings target. Other research has tried to determine whether the monitoring role of institutional investors is related with long-term or short-term investments. In relation to this, Hsu and Koh (2005) provide evidence that long-term institutional investors limit EM, while those of short-term institutional investors encourage high levels of income-enhancing accrual EM.

Events leading up to the 2002 and 2008 corporate scandals in the US and the subsequent financial crisis could strongly be attributed to the lack of vigorous corporate governance practices. In response to this, new legislations were promulgated to tighten the regulations relating to $C G$ and financial reporting in a number of countries including the US and UK. The Sarbanes Oxley Act enacted July 30, 2002, also known as the "Public Company Accounting Reform and Investor Protection Act" in the US was in response to this phenomenon (Ibrahim, Xu, \& Rogers, 2011).

\subsubsection{Corporate Governance in the UK}

The UK which has pieces of legislations and various reports (Cadbury Report, 1992; Greenbury Report, 1995; Turnbull Report, 1999) all relating to CG, consolidated these legislations and reports in an enhance form called the combined code to address CG failures that resulted in several corporate scandals in UK. The consolidation into the combined code was in July 2003, revised in June, 2006 and eventually the UK CG Code June, 2010.

The new code has some emphasis it is believed would help achieve good CG and helps curb unacceptable accounting practices. The main aspects of the code include;

a. Leadership role of boards providing direction to companies' management. The code emphasised that one person should not exercisethe roles of chairman and chief executive at the same time. The division of responsibilities between the chairman and chief executive should be clearly established, set out in writing and agreed by the board.

b. Effectiveness of the board considering its composition, independence, experience and skills in discharging its duties. The need for an elaborate, rigorous and transparent procedure to be followed for the appointment of new directors and also for directors to spend sufficient time to discharge their responsibilities effectively to the company.

c. Accountability in relation to financial and business reporting. The need for the board to determine the nature and extent of risk appropriate to enable it achieve its objectives. Maintain an effective system to manage risk and keep it at acceptable levels necessary for the company's business.

d. Remuneration levels and compensation for board and executives. Remuneration levels should be enough to attract, motivate and retain competent director needed to successfully administer a company. Should avoid excessive compensation particularly to executive directors and ensure remuneration is structured to link rewards to long term shareholder value creation.

e. Board relationship with shareholders by providing reports on operation through AGMs and other forums. Constructive use of AGMs to communicate with shareholders and encourage their participation. Ensure that shareholders are able to vote on major issues separately (FRC, 2010).

One striking feature of the UK CG Code is the refrain 'Comply or Explain'. This is seen as the trademark of the UK CG practice and has been in use since the beginning of the Code. According to the FRC (2010), this forms 
the foundation of the Code's flexibility and is strongly supported by both shareholders and companies and also widely admired and replicated internationally. The Code consists of principles and provisions rather than a set of rigid rules. Nonetheless, critics of this approach say that the 'comply or explain' rhetoric is lax and fails to hold violators of the code accountable since managers could violate the code and simply choose to give their own explanations.

This study is therefore to examine the extent to which these legislations particularly, the UK CG Code June, 2010 has prevented or reduced earnings management since its enactment.

\subsection{Research Question/Hypothesis}

Studies have provided evidence about earnings manipulation activities by managers for several reasons including M\&As (Henry \& Schmitt, 2001; Myers \& Majluf, 1984). Also, evidence exist that indicate EM around M\&As (Botsari \& Meeks, 2008; Rosa et al., 2003; Goodwin, 2009). Rosa et al. (2003) suggests a systematic EM is associated with the use of stock as payment in takeovers. The impact of CG on EM cannot be underestimated as research has shown that best corporate governance practices minimise EM and reduces fraud drastically (Hsu \& Koh, 2005; Osma, 2008).

The UK CG Code 2010 was enacted to strengthen and instil best corporate governance practice, transparent and factual financial reporting. The overriding purpose of UK CG Code is to protect investors by compelling corporate managers to adopt practices that safeguard the interest of shareholders and other stakeholders by increasing their level of participation and disclosure and also improving on CG practices.

\subsubsection{Research Question}

The research question is therefore as follows:

Is the UK Corporate Governance Code 2010 effective in reducing earnings management prior to mergers and acquisition among UK listed companies?

\subsubsection{Hypothesis}

Based on the questions above, the hypothesis to test is as below;

Hypothesis: The level of earnings management around Mergers and Acquisitions in the UK has significantly reduced after the enactment of the UK Corporate Governance code 2010.

\section{Data Sampling/Methodology}

\subsection{Introduction}

This section discusses the sample selection procedures and the methodology used in measuring discretionary accruals manipulation used in managing earnings in periods before and after the passage of the UK CG Code 2010.

\subsection{Sample Selection}

This study aims to provide empirical evidence on the effectiveness of the UK CG code 2010 in curbing EM around mergers and acquisitions in the UK. The sample used in this dissertation work is composed of 66 companies listed on the London Stock Exchange (LSE) that have undertaken M\&As from the period 2007 to 2014. This period is further divided into two, 33 companies involved in M\&As before May 2010 and another 33 companies after July 2010. The sample firms are restricted to nonfinancial firms and also exclude highly regulated utilities companies. These highly regulated firms have their own unique reporting procedures and requirements different from other firms and so their inclusion may distort the results.

The list of companies engaged in M\&As over the stated period is extracted from Data Stream, while the financial data for these companies is obtained from Bloomberg. Whilst there were over 3,500 M\&As activities in the UK over the period of 2007 to 2014 , over $90 \%$ of these M\&As paid their consideration in cash. Consideration payments in cash were excluded because studies have revealed there is no motivation for acquirers to engage in earnings management prior to acquisition when the consideration is paid in cash (Rosa et al., 2003; Goodwin, 2009). Acquisitions made between May 2010 and July 2010 have been excluded from the sampled firms in order to create the distinction between the pre and post CG Code 2010 periods.

After excluding the above companies, the sample was virtually left with M\&As that paid their consideration in share exchange over the period except for a few companies whose data was unavailable from Bloomberg that was further eliminated to arrive at the current sample size of 66 firms. 


\subsection{Methodology}

\subsubsection{Discretionary Accruals Models}

Quite a number of techniques exist for measuring discretionary accruals and detecting EM. These include simple techniques in which total accruals are used for measuring discretionary accruals to complex regression models that decompose accruals into discretionary (DA) and non-discretionary (NDA) components. They include the DeAngelo Model, the Healy Model (Healy, 1985), Jones (1991) Model and the modified Jones Model as developed by Dechow et al. (1995) amongst others.

The core method to be used in detecting EM in this study is through the modified version of Jones Model (Jones, 1991) as modified by Dechow et al. (1995). The reasons for using this model are its ability to compare results with those previous studies from elsewhere and also the fact that a significant body of academic literature has identified it as the most powerful model for detecting EM through abnormal accruals that result from managerial decisions to increase or smooth income (Cohen, Dey, \& Lys, 2008). The modified Jones model is widely used and is easily understood. Moreover, Dechow, Sloan, and Sweeney (1995) evaluated five different models of measuring discretionary accruals and conclude that the modified Jones Model works best.

\section{1) Modified Jones Model}

The modified Jones Model is estimated for each firm grouping as follows:

$$
D A_{i t}=\frac{T A_{i t}}{A_{i t-1}}-\left(\beta_{1}\left(\frac{1}{A_{i t-1}}\right)+\beta_{2}\left(\frac{\Delta R E V_{i t}-\Delta R E C_{i t}}{A_{i t-1}}\right)+\beta_{3}\left(\frac{P P E_{i t}}{A_{i t-1}}\right)+\varepsilon_{i t}\right)
$$

Where, for fiscal year $\mathrm{t}$ and firm $\mathrm{i}$;

DA stands for discretionary accruals (abnormal accruals);

TA stands for Total Accruals defined as: $\mathrm{TA}_{\mathrm{it}}=\mathrm{EBXI}_{\mathrm{it}}-\mathrm{CFO}_{\mathrm{it}}$, where EBXI is the earnings before extraordinary items anddiscontinued operations and $\mathrm{CFO}$ is the operating cashflows from continuing operations taken from the statement of cash flows;

$\mathrm{A}_{\mathrm{it}-1}$ represents lagged total assets;

$\triangle \mathrm{REV}_{\mathrm{it}}$ is the change in revenues from the preceding year;

$\triangle \mathrm{REC}_{\mathrm{it}}$ is change in receivables from the preceding year;

$\mathrm{PPE}_{\mathrm{it}}$ is the gross value of property, plant and equipment in year $t$ and

$\varepsilon_{i t}$ is the Error term in year $\mathrm{t}$ for the firm $\mathrm{i}$.

To run a regression and estimate the discretionary accruals (abnormal accruals), the variables used as in the modified Jones Model are; Total accruals, change in Revenue minus change in Receivables and Gross Property, Plant \& Equipment, each of which is scaled by lagged Total Assets. Estimating the discretionary accruals (DA) is done in two stages. These variables are put in a model to run a regression to find the coefficients $\beta_{1}, \beta_{2}$ and $\beta_{3}$ as follows;

$$
T A_{i t}=\beta_{1}\left(\frac{1}{A_{i t-1}}\right)+\beta_{2}\left(\frac{\Delta R E V_{i t}-\Delta R E C_{i t}}{A_{i t-1}}\right)+\beta_{3}\left(\frac{P P E_{i t}}{A_{i t-1}}\right)+\varepsilon_{i t}
$$

The next stage is using the coefficients of $\beta_{1}, \beta_{2}$ and $\beta_{3}$ obtained in the regression to substitute into model (1) with firm specific data to obtain DA.

Finally, the Non-Discretionary Accruals (NDA) is obtained by subtracting Discretionary Accruals from Total Accruals as shown below.

$$
D A_{i t}=\frac{T A_{i t}}{A_{i t-1}}-N D A, \text { therefore } \mathrm{NDA}=\frac{T A_{i t}}{A_{i t-1}}-D A_{i t}
$$

See model (1) for explanations.

The model (1) above is further decomposed as follows:

$$
D A_{i t}=\frac{T A_{i t}}{A_{i t-1}}-N D A
$$

Where, for sample firm $\mathrm{i}$ at time $\mathrm{t}$ 
NDA stands for Non-Discretionary Accruals (Normal accruals)

See model (1) for further explanations.

The modified Jones model assumes earnings would often be managed using discretion on revenue recognition by manipulating credit sales. The model therefore uses change in revenue, adjusted for change in receivables in the event period (Dechow et al., 1995). All other factors remain the same as in Jones (1991) Model.

\section{2) Pearson Product Moment Correlation}

In addition to the above model, the Pearson Product Moment Correlation has also been employed to measure the strength of the linear relationship between operating income and operating cash flows. Accounting income is prone to manipulation due to its nature, whereas cash flow is considered a more reliable indicator of firm's performance. Therefore, identifying the correlation between the two variables reflects the degree to which they are related. Vafeas et al. (2003) found that you could detect EM by comparing net income to operating cash flow. By observing the correlation between operating income and cash flows, unusual increases or decreases in net income can be identified and compared with the cash flow and hence reveal the possibility of EM. In exploring the use of correlation analysis in detecting earnings management, Leuz et al. (2003) measure the correlation between accounting accruals and operating cash flows and revealed some significant differences in EM across three different levels of stock markets.

Their assumption was that companies with a correlation in the range -1.0 to -0.3 engaged in earnings manipulation. They assumed the variables X (Earnings) and Y (Cash-flow) are normally distributed. The study categorized the values as a guideline as follows (Note 1):

- $\quad-1.0$ to -0.7 strong negative association (inverse).

- -0.7 to -0.3 weak negative association.

- -0.3 to +0.3 little or no association.

- $\quad+0.3$ to +0.7 weak positive association.

- $\quad+0.7$ to +1.0 strong positive association.

\section{Data Analysis and Results}

\subsection{Introduction}

This section looks at the data analysis and the results using the methodology stated in section three in detecting EM amongst the sample companies before and after the UK CG Code 2010.

Available literature provides enormous evidence that suggest management uses discretionary accruals in manipulating earnings upwards to induce their stock prices upwards around mergers and acquisitions elsewhere and the UK in particular (Botsari \& Meeks, 2008). By this, they effectively reduce the number of shares offered as consideration in a stock for stock offer. To find out the impact of the UK CG Code 2010 on such activities, the levels of discretionary accruals within sampled UK companies listed on the London Stock Exchange (LSE) that have undertaken M\&As involving stock for stock exchange was measured in the period January 2007 to December 2014. This period is divided into two; the Pre Corporate Governance period (Pre-CG) covering the period January 2007 to April 2010 and the Post Corporate Governance period (Post-CG) also covering September 2010 to December 2014.

\subsection{Earnings Management (Discretionary Accruals)}

The proxy used for estimating earnings manipulation is Discretionary Accruals (DA). The study measured DA using the Modified Jones Model as developed by Dechow et al., (1995) in the model below (Note 2).

$$
D A_{i t}=\frac{T A_{i t}}{A_{i t-1}}-\left(\beta_{1}\left(\frac{1}{A_{i t-1}}\right)+\beta_{2}\left(\frac{\Delta R E V_{i t}-\Delta R E C_{i t}}{A_{i t-1}}\right)+\beta_{3}\left(\frac{P P E_{i t}}{A_{i t-1}}\right)+\varepsilon_{i t}\right)
$$

Where, for fiscal year $\mathrm{t}$ and firm $\mathrm{i}$;

DA stands for discretionary accruals (abnormal accruals);

TA stands for total accruals defined as: $\mathrm{TA}_{\mathrm{it}}=\mathrm{EBXI}_{\mathrm{it}}-\mathrm{CFO}_{\mathrm{it}}$, where $\mathrm{EBXI}$ is the earnings before extraordinary items anddiscontinued operations and $\mathrm{CFO}$ is the operating cashflows from continuing operations taken from the statement of cash flows;

$\mathrm{A}_{i t-1}$ represents lagged total assets; 
$\triangle R E V_{i t}$ is the change in revenues from the preceding year;

$\triangle \mathrm{REC}_{i t}$ is change in receivables from the preceding year;

$\mathrm{PPE}_{\mathrm{it}}$ is the gross value of property, plant and equipment in year $t$ and

$\varepsilon_{i t}$ is the Error term in year $\mathrm{t}$ for the firm $i$.

The first stage in calculating DA is to obtain the coefficients $\beta_{1} \beta_{2} \beta_{3}$. Total Accruals (TA), Change in Revenue $\left(\triangle \mathrm{REV}_{\mathrm{it}}\right)$ minus Change in Receivables $\left(\triangle \mathrm{REC} \mathrm{C}_{\mathrm{it}}\right)$, Property, Plant \& Equipment $\left(\mathrm{PPE}_{\mathrm{it}}\right)$ extracted from sample companies' financial statements is regressed as in the model below to get the coefficients. All variables are divided by lagged Total assets $\left(\mathrm{A}_{\mathrm{it}-1}\right)$ for the reason that the sample companies are a combination of small and large companies with their financial data either large or small depending on the size of the companies (Note 3).

$$
\frac{T A_{i t}}{A_{i t-1}}=\beta_{1}\left(\frac{1}{A_{i t-1}}\right)+\beta_{2}\left(\frac{\Delta R E V_{i t}-\Delta R E C_{i t}}{A_{i t-1}}\right)+\beta_{3}\left(\frac{P P E_{i t}}{A_{i t-1}}\right)+\varepsilon_{i t}
$$

The coefficients of $\beta_{1}, \beta_{2}, \beta_{3}$ obtained from the regression above are combined with firms specific data as in themodel below to obtain DA.

$$
D A_{i t}=\frac{T A_{i t}}{A_{i t-1}}-\left(\beta_{1}\left(\frac{1}{A_{i t-1}}\right)+\beta_{2}\left(\frac{\Delta R E V_{i t}-\Delta R E C_{i t}}{A_{i t-1}}\right)+\beta_{3}\left(\frac{P P E_{i t}}{A_{i t-1}}\right)+\varepsilon_{i t}\right)
$$

NDA is calculated as $D A_{i t}=\frac{T A_{i t}}{A_{i t-1}}-N D A$, therefore; $N D A_{i t}=\frac{T A_{i t}}{A_{i t-1}}-D A_{i t}$

The regression showed that the coefficient for $\beta_{1}$ is not statistically significant in the model with a coefficient of 0.07822 and a $p$-value of 0.473 at $95 \%$ confidence level. However, the rest of the coefficients are significant. The next table 2 show the coefficients for $\beta_{2}, \beta_{3}$ which have been used in estimating DA after dropping the coefficient of $\beta_{1}$ because its $p$-value was insignificant.

\begin{tabular}{|c|c|c|c|c|c|c|c|c|}
\hline \multicolumn{9}{|l|}{ ANOVA } \\
\hline & $d f$ & $S S$ & $M S$ & $F$ & Significance $F$ & & & \\
\hline Regression & 3 & 0.1334 & 0.0445 & 3.3755 & 0.0238 & & & \\
\hline Residual & 62 & 0.8168 & 0.0132 & & & & & \\
\hline \multirow[t]{2}{*}{ Total } & 65 & 0.9502 & & & & & & \\
\hline & Coefficients & Standard Error & t Stat & P-value & Lower 95\% & Upper 95\% & Lower $95.0 \%$ & Upper $95.0 \%$ \\
\hline Intercept & -0.0010 & 0.0209 & -0.0503 & 0.9601 & -0.0428 & 0.0407 & -0.04277 & 0.04068 \\
\hline $1 / \mathrm{A} \mathrm{t}-1$ & 0.0782 & 0.1083 & 0.7224 & 0.4728 & -0.1382 & 0.2947 & -0.13823 & 0.29466 \\
\hline$(\triangle \mathrm{REV}-\triangle \mathrm{REC}) / \mathrm{At}-1$ & 0.1017 & 0.0469 & 2.1687 & 0.0339 & 0.0080 & 0.1955 & 0.00796 & 0.19551 \\
\hline PPE/A t-1 & -0.1078 & 0.0500 & -2.1570 & 0.0349 & -0.2077 & -0.0079 & -0.20773 & -0.00790 \\
\hline
\end{tabular}

Table 1. A regression to obtain the coefficients of $\beta_{1} \beta_{2} \beta_{3}$

Table 2. Second regression for the coefficients of $\beta_{2} \beta_{3}$

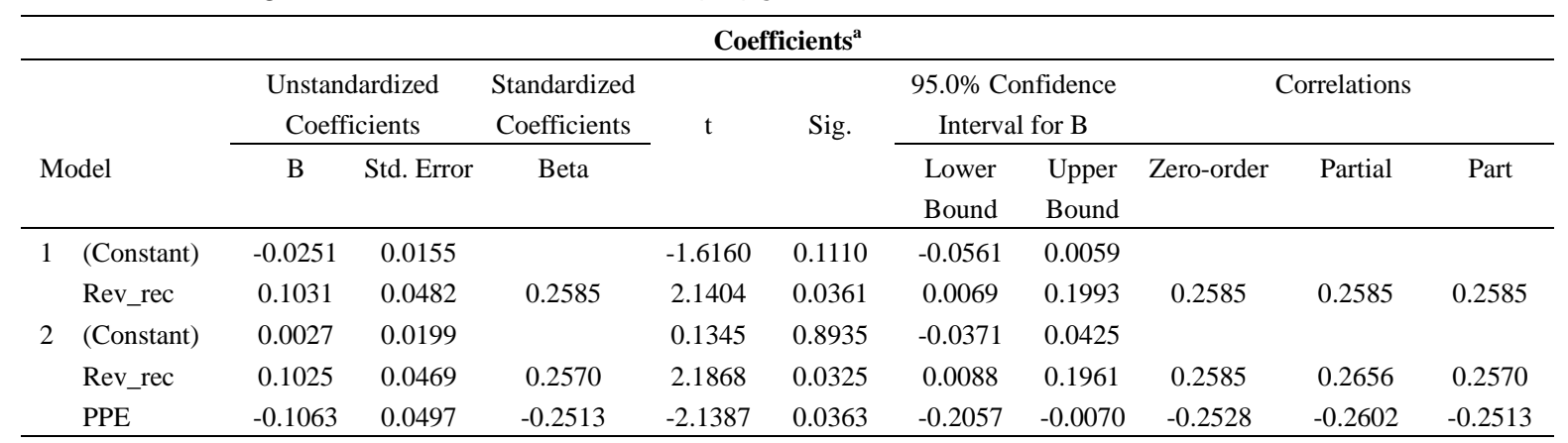

a. Dependent Variable: TA. 


\subsection{Descriptive Statistics}

Table 3 below shows the descriptive statistics for Pre Corporate Governance 2010 (Pre-CG) sampled companies whilst table 4 shows the Post Corporate Governance (Post-CG) sample. It is observed that the total for $T A_{i t}$ in the Pre-CG is +0.551 with a mean of +0.017 . Total DA in the same period is +0.9198 with a mean of +0.0279 . This suggests an increase in discretionary accruals (abnormal accruals). It is interesting to note that the total $T A_{i t}$ for the Post-CG is -1.4425 whilst its mean is -0.0437 . Total DA for the same period is -0.9397 with a mean of -0.0285 suggesting some form of decreasing accruals. The NDA or normal accruals registered a mean and median of -0.0112 for the Pre-CG period and -0.0118 for the Post-CG period with total NDA as -0.3686 . On the other hand, the Post-CG period has a mean and median of -0.0152 and -0.0031 respectively also indicating income increasing accruals in the pre-CG period and income decreasing accruals in the post-CG period.

Table 3. Pre-corporate governance 2010 descriptive statistics

\begin{tabular}{llccccc}
\hline DETAILS & 1/A t-1 & $(\Delta$ REV- $\mathbf{A R E C}) / \mathbf{A t}-\mathbf{1}$ & $\mathbf{P P E} / \mathbf{A}$ t-1 & T A it/A t-1 & NDA & DA \\
\hline Mean & 0.0721 & 0.0645 & 0.1924 & 0.0167 & -0.0112 & 0.0279 \\
Median & 0.0028 & 0.0008 & 0.0647 & -0.0060 & -0.0118 & 0.0100 \\
Std Deviation & 0.1702 & 0.2715 & 0.2513 & 0.1394 & 0.0387 & 0.1248 \\
Maximum & 0.7020 & 1.0750 & 1.0664 & 0.6173 & 0.0982 & 0.5191 \\
Minimum & 0.0001 & -0.2883 & 0.0000 & -0.1977 & -0.1058 & -0.1833 \\
Total & 2.3802 & 2.1271 & 6.3485 & 0.5512 & -0.3686 & 0.9198 \\
Count & 33.00 & 33.00 & 33.00 & 33.00 & 33.00 & 33.00 \\
\hline
\end{tabular}

Table 4. Post-corporate governance 2010 descriptive statistics

\begin{tabular}{lcccccc}
\hline DETAILS & 1/A t-1 & $(\Delta$ REV- $\mathbf{A R E C}) / A t-1$ & PPE/A t-1 & T A it/A t-1 & NDA & DA \\
\hline Mean & 0.0276 & 0.1663 & 0.3288 & -0.0437 & -0.0152 & -0.0285 \\
Median & 0.0058 & 0.0989 & 0.1697 & -0.0502 & -0.0031 & -0.0481 \\
Std Deviation & 0.0645 & 0.3202 & 0.2961 & 0.0869 & 0.0474 & 0.0884 \\
Maximum & 0.3515 & 0.8235 & 1.1171 & 0.1650 & 0.0726 & 0.1652 \\
Minimum & 0.0001 & -0.8963 & 0.0003 & -0.1920 & -0.1124 & -0.1908 \\
Total & 0.9121 & 5.4890 & 10.8516 & -1.4425 & -0.5028 & -0.9397 \\
Count & 33.00 & 33.00 & 33.00 & 33.00 & 33.00 & 33.00 \\
\hline
\end{tabular}

The hypothesis for this study is that level of income increasing discretionary accruals prior to M\&As in the UK is significantly reduced after the enactment of the UK Corporate Governance code 2010. The results shown in tables $3 \& 4$ support the hypothesis. In effect, the results suggest some level of income increasing accruals manipulation prior to M\&As in the Pre-CG periods whilst indicating the reverse in the post-CG period.

ANOVA analysis was done to assess whether the means of the two groups (Pre \& Post-CG DA) arc statistically different from each other, that is, if the two means differ significantly. Table 5 below shows that the means of the two periods are statistically different and significant at $95 \%$ confidence interval. It shows a $p$-value of 0.04108 which is less than 0.05 and $F$-value of 4.3466 which is greater than the $F$ critical of 3.9909. The mean DA for Pre-CG is +0.02787 with a variance of +0.01605 suggesting some level of increasing discretionary accruals in the Pre-CG period prior to stock for stock M\&As amongst UK companies. Though the mean for DA in Post-CG is -0.02847 indicating income decreasing accruals activity, its variance is +0.00805 , suggesting the level of decreasing accruals may not necessarily be to depress income but rather to comply with the new regulations introduced, the Corporate Governance code 2010. 
Table 5. Anova analysis for significance of the means of Pre \& Post-CG DA

\begin{tabular}{|c|c|c|c|c|c|c|}
\hline \multicolumn{5}{|c|}{ Anova: Single Factor } & & \\
\hline Groups & Count & Sum & Average & Variance & & \\
\hline Pre CG & 33 & 0.91977 & 0.02787 & 0.01605 & & \\
\hline Post CG & 33 & -0.93967 & -0.02847 & 0.00805 & & \\
\hline \multicolumn{7}{|l|}{ Anova } \\
\hline $\begin{array}{l}\text { Source } \\
\text { Variation }\end{array}$ & $S S$ & $d f$ & MS & $\mathrm{F}$ & $P$-value & $F$ crit \\
\hline Between Groups & 0.0524 & 1 & 0.05239 & 4.34660 & 0.04108 & 3.99092 \\
\hline Within Groups & 0.7713 & 64 & 0.01205 & & - & \\
\hline Total & 0.8237 & 65 & & & & \\
\hline
\end{tabular}

The results in this study is consistent with other studies elsewhere that evince the effect of regulations in minimising malpractices in financial reporting including earnings management practices. As in the case of Sarbox, Cohen et al. (2008) found that it reduce accruals earnings management significantly.

\subsection{Pearson Product Moment Correlation}

The Pearson product moment correlation was performed between profit before extra-ordinary items (PBXOI) and Cash Flow from operation (CFO) for the Pre-CG period and the Post-CG period. The results produced a coefficient of +0.8634 or $86.34 \%$ for the Pre-CG period suggesting a strong relationship between profit and cash flow. It produced a coefficient of +0.4315 Or $43.15 \%$ for the Post-CG period suggesting a weak relationship between profit and cash flow. These results would therefore be interpreted as showing no earnings management activities within both periods since the coefficients in both periods are positive.

However, the results show an unusual change in the coefficients from the Pre-CG value of +0.8634 to Post-CG value of +0.4315 . This suggests some level of change in activity in earnings between the Pre and Post CG period and could be attributed to effect from the introduction of the corporate governance code 2010. One could not conclude the existence of EM within these periods amongst M\&As involving stock for stock based on the correlation coefficients but it is worthy to note some unusual changes in activities in the earnings of sample companies between the two periods. Some further interrogation of the data may reveal some more insight on the behaviour of stock for stock acquisitions in the UK. The Pearson product moment correlation coefficient therefore suggest the CG code had an effect on the reported earnings of M\&As resulting in the changes in Pearson correlation coefficients in the two periods.

In summary, the results from the modified Jones (1991) model as designed by Dechow et al. (1995) indicate firms engaged in EM before the CG code 2010 but reversed this behaviour after the CG code 2010. A test for significance showed the results were significance with a $p$-value of 0.04108 . However, using the Pearson product moment correlation coefficient could not conclude the existence of EM but indicate some change in activity with the coefficient for pre and post CG period of 0.8634 and 0.4315 respectively.

\section{Conclusion}

\subsection{Summary of Findings}

Several studies revealed EM around M\&As by both acquirers and target firms. This and other corporate malpractices have prompted authorities to tighten regulations by passing the UK CG Code to guide companies in the UK in their financial reporting.

This study is conducted to investigate the impact of the UK CG code on accruals EM around M\&As in the UK. The study applied the Jones (1991) model as modified by Dechow et al. (1995) and the Pearson product moment correlation in analysing a sample data from 66 companies listed on the LSE that have undertaken M\&As within the period of January 2007 to December 2014. These sample companies were further divided into two, the pre-CG up to April 2010 and the post-CG from September 2010 to December 2014.

The results produced by the modified Jones model indicate some level of income increasing discretionary accruals in the pre-CG period but showed an opposite situation in the post-CG period. A test for significance showed significant difference between the means of Pre-CG DA and Post-CG DA to accept the hypothesis that "the level of earnings management around Mergers and Acquisitions in the UK has significantly reduced after the enactment of the UK Corporate Governance code 2010". However, the Pearson correlation coefficient was inconclusive about the existence of EM among the sample companies but indicates some changes in the level of 
activities in the earnings between the two periods. This therefore points to the fact that the CG code had an effect on the reported earnings of these companies.

The results from this study is consistent with existing studies that evince the effectiveness of CG in controlling EM as Hsu and Koh (2005); Osma (2008) suggest that best corporate governance practices minimise EM and reduces fraud drastically. In the case of Sarbox, Cohen el al. (2008), found that it reduce accruals EM significantly and a shifted to using real accounting earnings manipulation.

\subsection{Limitations of the Study}

The necessary care was taken during the conduct of this study to ensure reliability of the result; however there exist some inherent limitations in the study which need to be noted. The study used secondary data extracted from other sources that may have their own limitations. Also, the sample size was limited since it was only 66 companies. Larger sample size of over 1,000 companies would have increase the robustness of the result.

One other limitation is that only discretionary accruals EM was tested to ascertain the effectiveness of the CG code. The use of real EM manipulations was not included in the study. Firms could therefore shift from accruals based to real activities based earnings manipulation. Finally, time constrain was another issue since the study was conducted in the spate of three months which did not allow enough time to thoroughly examine other issues around the study area.

A further study is suggested to be conducted using real activities based and accruals based EM detecting methods to establish whether managers did not shift from accruals EM manipulations to real activities to avoid detection. The study will provide feedback to regulators as to the effectiveness of the regulations and further course of action required to ensure good corporate governance, strong financial reporting that will boost investor confidence and increase investments and economic activities in the UK.

\subsection{Recommendations}

The findings from this study indicate that the UK CG code 2010 has an impact on EM around M\&As and that the CG is effective in minimising accruals EM around M\&As in the UK. Regulatory authorities should therefore monitor activities of firms and ensure compliance to the Code. Even though the Code provides a window for firms to explain their inability to comply with the provisions of Code, the regulatory authorities would have to ensure that managers of firms do not hide behind that window to engage in practices that are not in tandem with the spirit of the Code. The UK CG Code should therefore be regularly revised to keep with current developments and remain relevant for protecting businesses and investors interest.

\section{References}

Andrade, G., Mitchell, M., \& Stafford, E. (2001). New Evidence and Perspectives on Mergers. Journal of Economic Perspectives, 15(2), 103-120. http://dx.doi.org/10.1257/jep.15.2.103

Ben-David, I., \& Darren, T. R. (2008). Why do small stock acquirers underperform in the long-term? University of Chicago Working Paper.

Bergstresser, D., \& Philippon, T. (2006). CEO incentives and earnings management. Journal of Financial Economics, 80(3), 511-529. http://dx.doi.org/10.1016/j.jfineco.2004.10.011

Berk, J., \& DeMarzo, P. (2014). Corporate Finance (3rd ed., pp. 931-952). Harlow, Essex CM20 2JE: Pearson Education Limited.

Botsari, A., \& Meeks, G. (2008). Do Acquirers Manage Earnings Prior to a Share for Share Bid? Journal of Business Finance \& Accounting, 35(5-6), 633-670. http://dx.doi.org/10.1111/j.1468-5957.2008.02091.x

Bushee, B. (1998). The Influence of Institutional Investors on Myopic R\&D Investment Behaviour. American Accounting Association, 73(3), 305-333.

Cazier, R. (2009). R\&D Spending Among Short-Horizon CEOs: A Re-Examination. SSRN Journal. http://dx.doi.org/10.2139/ssrn.1532270

Cheng, Q., \& Warfield, T. (2005). Equity Incentives and Earnings Management. The Accounting Review, 80(2), 441-476. http://dx.doi.org/10.2308/accr.2005.80.2.441

Chung, R., Firth, M., \& Kim, J. (2002). Institutional monitoring and opportunistic earnings management. Journal of Corporate Finance, 8(1), 29-48. http://dx.doi.org/10.1016/S0929-1199(01)00039-6

Cohen, D., Dey, A., \& Lys, T. (2008). Real and Accruals Based Earnings Management in the Pre- and Post Sarbanes Oxley Periods. The Accounting Review, 83(3), 757-787. 
http://dx.doi.org/10.2308/accr.2008.83.3.757

Cornett, M., Marcus, A., \& Tehranian, H. (2008). Corporate governance and pay-for-performance: The impact of earnings management. Journal of Financial Economics, 87(2), $357-373$. http://dx.doi.org/10.1016/j.jfineco.2007.03.003

Dechow, P. M., Sloan, R. G., \& Sweeney, A. P. (1995). Detecting Earnings Management. The Accounting Review, 70, 193-225.

Dechow, P., \& Sloan, R. (1991). Executive incentives and the horizon problem. Journal of Accounting and Economics, 14(1), 51-89. http://dx.doi.org/10.1016/0167-7187(91)90058-S

Erickson, M., \& Wang, S. (1999). Earnings management by acquiring firms in stock-for-stockmergers. Journal of Accounting and Economics, 27, 149-176. http://dx.doi.org/10.1016/S0165-4101(99)00008-7

Goodwin, E. (2009). Earnings Management Around Mergers and Acquisitions (p. 2). Doctor of Business Administration, College of Business Louisiana Tech University.

Graham, J., Harvey, C., \& Rajgopal, S. (2005). The economic implications of corporate financial reporting. Journal of Accounting and Economics, 40(1-3), 3-73. http://dx.doi.org/10.1016/j.jacceco.2005.01.002

Gunny, K. (2010). The Relation Between Earnings Management Using Real Activities Manipulation and Future Performance: Evidence from Meeting Earnings Benchmarks. Contemporary Accounting Research, 27(3), 855-888. http://dx.doi.org/10.1111/j.1911-3846.2010.01029.x

Healy, P. (1985). The effect of bonus schemes on accounting decisions. Journal of Accounting and Economics, 7(1-3), 85-107. http://dx.doi.org/10.1016/0165-4101(85)90029-1

Healy, P. M., \& Wahlen, J. M. (1999). A review of the earnings management literature and its implications for standard setting. Accounting Horizons, 13, 365-383. http://dx.doi.org/10.2308/acch.1999.13.4.365

Henry, D., \& Schmitt, C. (2001). The Numbers Game. Business Week, No. 3732, 100-107.

Hsu, G., \& Koh, P. (2005). Does the Presence of Institutional Investors Influence Accruals Management? Evidence from Australia. Corporate Governance: An International Review, 13(6), 809-823. http://dx.doi.org/10.1111/j.1467-8683.2005.00472.x

Ibrahim, S., Xu, L., \& Rogers, G. (2011). Real and accrual based earnings management and its legal consequences. Accounting Research Journal, 24(1), 50-78. http://dx.doi.org/10.1108/10309611111148779

Jensen, M., \& Meckling, W. (1976). Theory of the firm: Managerial behaviour, agency costs and ownership $\begin{array}{lllll}\text { structure. } \quad \text { Journal } & \text { Financial } & \text { Economics, } & 305-360 .\end{array}$ http://dx.doi.org/10.1016/0304-405X(76)90026-X

Jones, J. (1991). Earnings Management during Import Relief Investigations. Journal of Accounting Research, 29, 193-228. http://dx.doi.org/10.2307/2491047

Kasznik, R. (1999). On the Association between Voluntary Disclosure and Earnings Management. Journal of Accounting Research, 37(1), 57. http://dx.doi.org/10.2307/2491396

Keasey, K., Thompson, S., \& Wright, M. (Eds.). (2005). Corporate governance: Accountability, enterprise and international comparisons. London: Wiley.

Klein, A. (2002). Audit committee, board of director characteristics, and earnings management. Journal of Accounting and Economics, 33(3), 375-400. http://dx.doi.org/10.1016/S0165-4101(02)00059-9

Koumanakos, E., Siriopoulos, C., \& Georgopoulos, A. (2005). Firm acquisitions and earnings management: Evidence from Greece. Managerial Auditing Journal, $20(7), \quad 669$. http://dx.doi.org/10.1108/02686900510611212

Laux, C., \& Laux, V. (2009). Board Committees, CEO Compensation, and Earnings Management. The Accounting Review, 84(3), 869-891. http://dx.doi.org/10.2308/accr.2009.84.3.869

Louis, H. (2004). Earnings management and the market performance of acquiring firms. Journal of Financial Economics, 74(1), 121-148. http://dx.doi.org/10.1016/j.jfineco.2003.08.004

Moeller, S., Schlingemann, F., \& Stulz, R. (2005). Wealth Destruction on a Massive Scale? A Study of Acquiring-Firm Returns in the Recent Merger Wave. Journal of Finance, 60(2), 757-782. http://dx.doi.org/10.1111/j.1540-6261.2005.00745.x

Myers, S., \& Majluf, N. (1984). Corporate financing and investment decisions when firms have information that 
investors do not have. Journal of Financial Economics, 13(2), 187-221. http://dx.doi.org/10.1016/0304-405X(84)90023-0

Osma, B. (2008). Board Independence and Real Earnings Management: The Case of R\&D Expenditure. Corporate Governance: An International Review, 16(2), 116-131. http://dx.doi.org/10.1111/j.1467-8683.2008.00672.x

Perry, S., \& Williams, T. (1994). Earnings management preceding management buyout offers. Journal of Accounting and Economics, 18(2), 157-179. http://dx.doi.org/10.1016/0165-4101(94)00362-9

Rahman, R. A., \& Bakar, A. A. (2002). Earnings Management and Acquiring Firms Preceding Acquisitions in Malaysia. Working Paper, University Technology Mara.

Roll, R. (1986). The Hubris Hypothesis of Corporate Takeovers. The Journal of Business, 59(2), 197-216. http://dx.doi.org/10.1086/296325

Rosa, R. da S., Sheung, A., \& Walter, T. (2003). is Earnings Management Systematically Associated with the Use of Stock Payment in Takeovers? Accounting Foundation at the University of Sydney and the School of Accountancy at the university of Technology, Sydney, Working paper, February.

Rossi, S., \& Volpin, P. (2004). Cross-country determinants of mergers and acquisitions. Journal of Financial Economics, 74(2), 277-304. http://dx.doi.org/10.1016/j.jfineco.2003.10.001

Roychowdhury, S. (2006). Earnings Management through Real Activities Manipulation. Journal of Accounting and Economics, 42, 335-370. http://dx.doi.org/10.1016/j.jacceco.2006.01.002

Strong, J., \& Meyer, J. (1987). Asset Write downs: Managerial Incentives and Security Returns. The Journal of Finance, 42(3), 643. http://dx.doi.org/10.1111/j.1540-6261.1987.tb04574.x

Vafeas, N., Vlittis, A., Katranis, P., \& Ockrce, K. (2003). Earnings management around share repurchases: A note. Abacus, 39(2), 250-261. http://dx.doi.org/10.1111/1467-6281.00130

Watts, R. L., \& Zimmerman, J. L. (1986). Positive accounting theory. Englewood Cliffs, NJ: Prentice-Hall.

Yang, J., \& Krishnan, J. (2005). Audit Committees and Quarterly Earnings Management. International Journal of Auditing, 9(3), 201-219. http://dx.doi.org/10.1111/j.1099-1123.2005.00278.x

Zang, A. (2012). Evidence on the Trade-Off between Real Activities Manipulation and Accrual-Based Earnings Management. The Accounting Review, 87(2), 675-703. http://dx.doi.org/10.2308/accr-10196

\section{Appendix}

\section{Descriptive Statistics}

\begin{tabular}{lccc}
\hline & Mean & Std. Deviation & $\mathrm{N}$ \\
\hline TA & -.0132 & .12099 & 66 \\
One_over_Assets & .0488 & .13179 & 66 \\
Rev_rec & .1156 & .30340 & 66 \\
PPE & .2606 & .28600 & 66 \\
\hline
\end{tabular}

\section{Correlations}

\begin{tabular}{llcccc}
\hline & & TA & One_over_Assets & Rev_rec & PPE \\
\hline Pearson Correlation & TA & 1.000 & .101 & .258 & -.253 \\
& One_over_Assets & .101 & 1.000 & -.001 & -.049 \\
& Rev_rec & .258 & -.001 & 1.000 & -.006 \\
& PPE & -.253 & -.049 & -.006 & 1.000 \\
\hline Sig. (1-tailed) & TA &. & .209 & .018 & .020 \\
& One_over_Assets & .209 &. & .497 & .348 \\
& Rev_rec & .018 & .497 &. & .481 \\
& PPE & .020 & .348 & .481 &. \\
\hline N & TA & 66 & 66 & 66 & 66 \\
& One_over_Assets & 66 & 66 & 66 & 66 \\
& Rev_rec & 66 & 66 & 66 & 66 \\
& PPE & 66 & 66 & 66 & 66 \\
\hline
\end{tabular}


Variables Entered/Removed $^{\text {a }}$

\begin{tabular}{|c|c|c|c|c|c|}
\hline Model & Variables Entered & Variables Removed & Method & & \\
\hline 1 & Rev_rec & & $\begin{array}{l}\text { Stepwise (Criteria: Probability-of-F-to-enter } \\
\text { Probability-of-F-to-remove }>=.100) .\end{array}$ & $<=$ & .050 \\
\hline 2 & PPE & & $\begin{array}{l}\text { Stepwise (Criteria: Probability-of-F-to-enter } \\
\text { Probability-of-F-to-remove }>=.100 \text { ) }\end{array}$ & $<=$ & .050 \\
\hline
\end{tabular}

a. Dependent Variable: TA.

\section{Model Summary ${ }^{\mathrm{c}}$}

\begin{tabular}{|c|c|c|c|c|c|c|c|c|c|c|}
\hline \multirow[b]{2}{*}{ Model } & \multirow[b]{2}{*}{$\mathrm{R}$} & \multirow[b]{2}{*}{ R Square } & \multirow[b]{2}{*}{$\begin{array}{l}\text { Adjusted R } \\
\text { Square }\end{array}$} & \multirow[b]{2}{*}{$\begin{array}{l}\text { Std. Error of } \\
\text { the Estimate }\end{array}$} & \multicolumn{5}{|c|}{ Change Statistics } & \multirow[b]{2}{*}{ Durbin-Watson } \\
\hline & & & & & $\begin{array}{l}\text { R Square } \\
\text { Change }\end{array}$ & F Change & df1 & df 2 & $\begin{array}{l}\text { Sig. F } \\
\text { Change }\end{array}$ & \\
\hline 1 & $.258^{\mathrm{a}}$ & .067 & .052 & .11778 & .067 & 4.581 & 1 & 64 & .036 & \\
\hline 2 & $.361^{\mathrm{b}}$ & .130 & .102 & .11463 & .063 & 4.574 & 1 & 63 & .036 & 1.617 \\
\hline
\end{tabular}

a. Predictors: (Constant), Rev_rec

b. Predictors: (Constant), Rev_rec, PPE

c. Dependent Variable: TA

ANOVA $^{a}$

\begin{tabular}{llrrrrr}
\hline Model & & Sum of Squares & df & Mean Square & F & Sig. \\
\hline 1 & Regression & .064 & 1 & .064 & 4.581 & $.036^{\mathrm{b}}$ \\
& Residual & .888 & 64 & .014 & & \\
& Total & .951 & 65 & & & $.012^{\mathrm{c}}$ \\
& Regression & .124 & 2 & .062 & 4.706 & \\
& Residual & .828 & 63 & .013 & & \\
& Total & .951 & 65 & & & \\
\hline
\end{tabular}

a. Dependent Variable: TA

b. Predictors: (Constant), Rev_rec

c. Predictors: (Constant), Rev_rec, PPE

\section{Excluded Variables ${ }^{\mathrm{a}}$}

\begin{tabular}{lcccccc}
\hline & & & & \multicolumn{2}{c}{ Partial } & \multicolumn{2}{c}{ Collinearity Statistics } \\
Model & & Beta In & $\mathrm{t}$ & Sig. & Correlation & Tolerance \\
\hline 1 & One_over_Assets & $.102^{\mathrm{b}}$ & .839 & .404 & .105 & 1.000 \\
& PPE & $-.251^{\mathrm{b}}$ & -2.139 & .036 & -.260 & 1.000 \\
2 & One_over_Assets & $.089^{\mathrm{c}}$ & .758 & .451 & .096 & .998 \\
\hline
\end{tabular}

a. Dependent Variable: TA

b. Predictors in the Model: (Constant), Rev_rec

c. Predictors in the Model: (Constant), Rev_rec, PPE

\section{Residuals Statistics ${ }^{\mathrm{a}}$}

\begin{tabular}{lrrrrr}
\hline & \multicolumn{1}{c}{ Minimum } & \multicolumn{1}{c}{ Maximum } & \multicolumn{1}{c}{ Mean } & \multicolumn{1}{c}{ Std. Deviation } & N \\
\hline Predicted Value & -.1123 & .0974 & -.0132 & .04362 & 66 \\
Residual & -.18911 & .52255 & .00000 & .11285 & 66 \\
Std. Predicted Value & -2.273 & 2.536 & .000 & 1.000 & 66 \\
Std. Residual & -1.650 & 4.559 & .000 & .984 & 66 \\
\hline
\end{tabular}

a. Dependent Variable: TA 

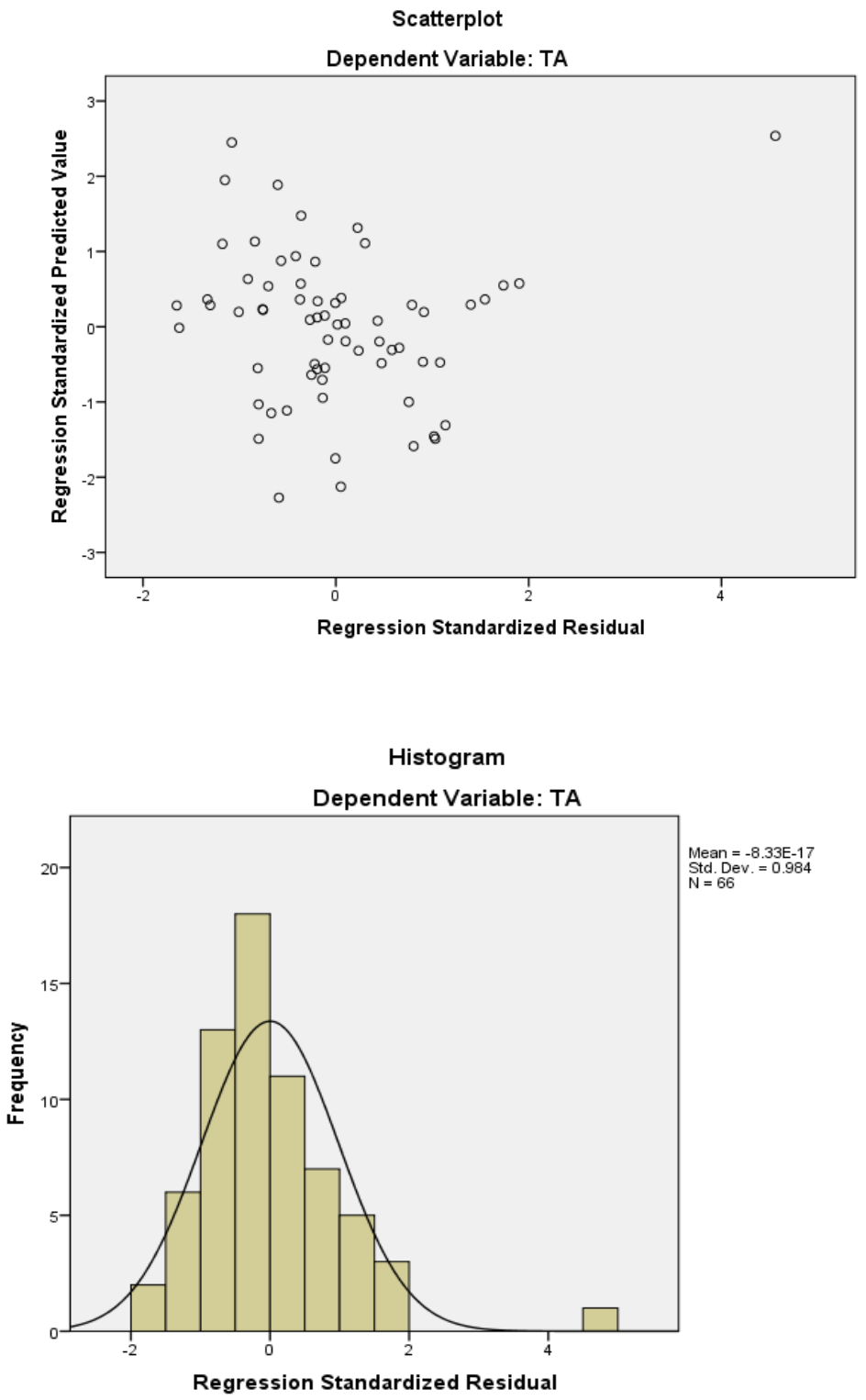

Normal P-P Plot of Regression Standardized Residual

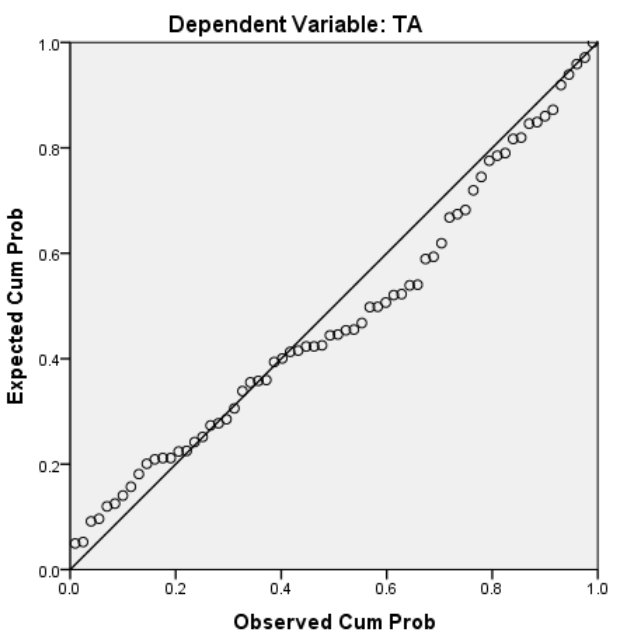




\section{Notes}

Note 1 . The coefficients range from +1 to -1 . A correlation coefficient of +1 means a perfect positive linear relationship between variables. A positive correlation is therefore evidence that large values of $\mathrm{X}$ are associated with large values of $\mathrm{Y}$ and small values of $\mathrm{X}$ are associated with small values of $\mathrm{Y}$. A negative correlation is evidence of the reverse.

Note 2. The year $t$ refers to the firms' financial year just ending at least two months before the announcement of merger to the public. $t$ - 1 is therefore the financial year just ending before year $t$.

Note 3. All variables are divided by Total Assets $\left(A_{i t-1}\right)$ to reduce heteroscedasticity for the reason that the sample companies are a combination of small and large companies with financial data for the companies being large or small depending on the size of the companies. Dividing through by lagged total assets scales all the data to a uniform data to avoid the influence of extreme values.

Total Accruals (TA) is calculated as Profit before extra-ordinary items minus Cash Flow from operations, Change in Revenue: - current year sales revenue minus previous year sales revenue and Change in Receivables as current year receivables minus previous year receivables.

The overall regression of all the variables is statistically significant with $f$ significance of 0.0238 . With SPSS, the insignificant coefficient is automatically dropped as the results are shown in table two above.

\section{Copyrights}

Copyright for this article is retained by the author(s), with first publication rights granted to the journal.

This is an open-access article distributed under the terms and conditions of the Creative Commons Attribution license (http://creativecommons.org/licenses/by/3.0/). 